\title{
George Buchanan's Unpublished Poems
}

\author{
PHILIP FORD \\ Clare College, Cambridge
}

Dans un article important paru dans The Library en 1969, et intitulé "George Buchanan's Latin Poems from Script to Print ", Ian McFarlane a établi les bases d'une éventuelle édition critique des poèmes de l'humaniste écossais. Enfouis dans les différents manuscrits contenant ses cuvres, la plupart se trouvant à la Bibliothèque nationale de France, on trouve une vingtaine de poèmes de longueurs variées qui nont jamais été imprimés et publiés. Certains poèmes sont courts, parfois des épigrammes obscènes, et des satires sur certains aspects de l'Église catholique; mais d'autres sont de longs poèmes adressés à des personnalités importantes telles que Gaspard de Coligny, assassiné au début du massacre de la Saint Barthélemy en 1572, ou son décrié collègue portugais, Beleago. D’autres sont des œuvres moins satiriques, comme le poème élégiaque intitulé "Omnia vincit amor " dans lequel le poète tente de se libérer de la tyrannie de l'amour, pour admettre en bout de ligne sa puissance conquérante. Cet article propose une analyse de ces poèmes, examine les raisons de leur apparente omission dans les ceuvres publiées de Buchanan, et évalue leur importance dans le contexte de sa poésie profane.

\" 1969, Ian McFarlane published an important article in The Library entitled "George Buchanan's Latin Poems from Script to Print," which provided a comprehensive survey of the manuscript collections in which the Scottish humanist's works appeared, and of the early editions of his works. ${ }^{1}$ As always, McFarlane's research is thorough and meticulous, and provides a more than sound basis for an understanding of Buchanan's attitude towards publication, as well as of the manuscript circulation that his poetry enjoyed before it appeared in print in the 1560s. Unlike many of his contemporaries, such as Théodore de Bèze and Marc-Antoine Muret, Buchanan appears to have been genuinely unconcerned about seeing his secular poems in print, although it is clear that they enjoyed a fairly extensive manuscript dissemination. ${ }^{2}$ The purpose of this

Renaissance and Reformation / Renaissance et Réforme 36.4, Fall / automne 2013 
paper is to consider those poems that were, for whatever reason, omitted from the editions of the secular poetry, which first appeared when Buchanan had just turned 60 and which proved so popular during his lifetime and for much of the following century. The vast majority of these appear in two manuscripts to be found in the Bibliothèque nationale de France - ms lat. 8140 and 8141 - which shall be the focus of this article.

The advantage of concentrating on these two manuscripts is that they also contain manuscript versions of the majority of Buchanan's published worksome of which did not get into print. Thus, by offering poems that did not make it into print, alongside others that did, the manuscripts may give us insight into underlying reasons for omission. Establishing the motives for their omission will be part of what I hope to achieve here. Unpublished poems in other manuscripts tend to be more sporadic.

The two manuscripts in question both represent attempts to gather together Buchanan's secular poems, though they are slightly different in nature. Ms lat. 8140 consists of eleven separate sections, in different hands, each produced with varying degrees of care, completed by an index. Ms lat. 8141 is somewhat shorter, consisting of five sections, but containing some unusual elements. The unpublished poems to be found in these two collections often occur in more than one section, frequently present variants, and give a good sense of the range of unpublished poems which were generally attributed to Buchanan. The following table provides a summary of what is present in them.

\begin{tabular}{|l|l|}
\hline BnF ms lat. 8140 & BnF ms lat. 8141 \\
\hline Section a & Section a \\
f. 8v: "In monachum" & f. 1r: Georgii Bucanani / In scarabeum \\
f. 9r: "In eundem" (i.e. Scaraboeus) & f. 10v-11r: "Ad eandem": "Forte sub- \\
Section b & ærato quod fulgiat ammulus auro" [sic] \\
f. 23v: "In Mon." & Section b \\
f. 40v-41r: "In Scarabeum" & f. 28r-28v: "Omnia vincit amor" \\
Section c & f. 28v-29r: "Quum pater omnipotens \\
f. 42r: "Efficite absentes dolor hic ne tan- & rubrae de[illegible] massae" \\
gat amicos" (12-line epigram in elegiac & f. 40r: "De quodam monacho ex Gal- \\
couplets) & lico": "Cum monachus monacham" \\
& \\
\hline
\end{tabular}




\begin{tabular}{|c|c|}
\hline 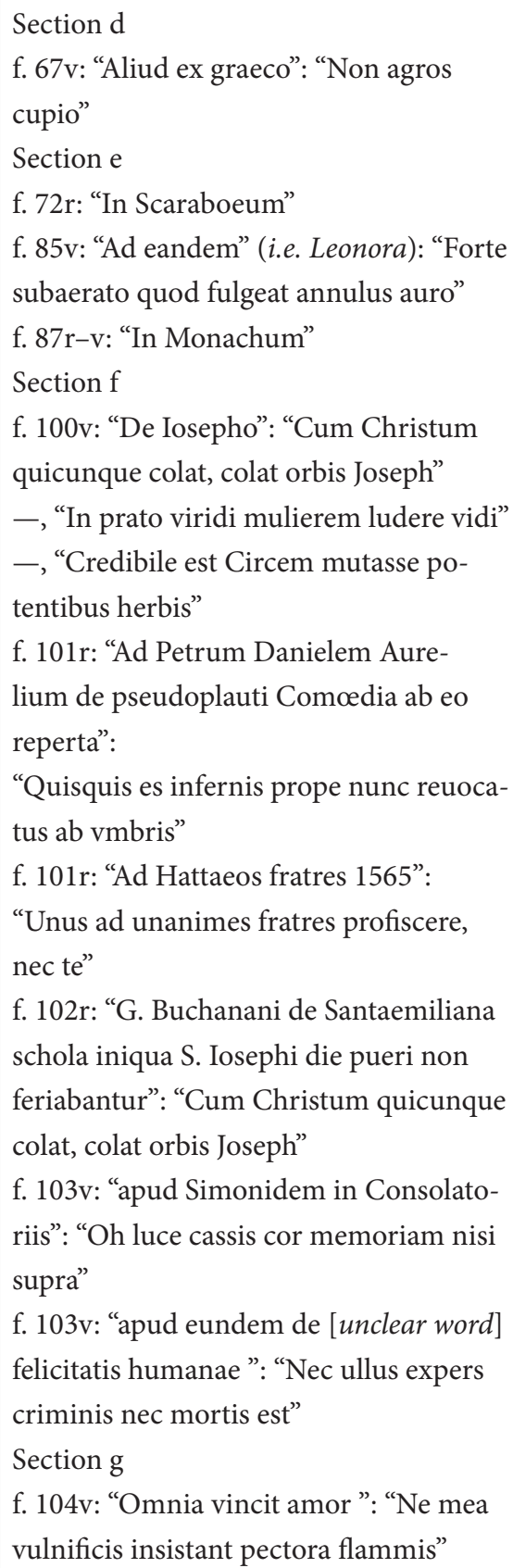 & $\begin{array}{l}\text { Section d } \\
\text { f. 58r: "In Quintum": "Auxilium fortuna } \\
\text { tibi res perfida, Quinte" } \\
\text { Section e } \\
\text { f. 59r: "Ad Michaelem, Thomam Petrum } \\
\text { Esquemios Montanos Burdigalenses": } \\
\text { "Gloria castalij fontis montana Iuuentus" } \\
\text { f. 67r: "Cum Christum quicunque colit" }\end{array}$ \\
\hline
\end{tabular}




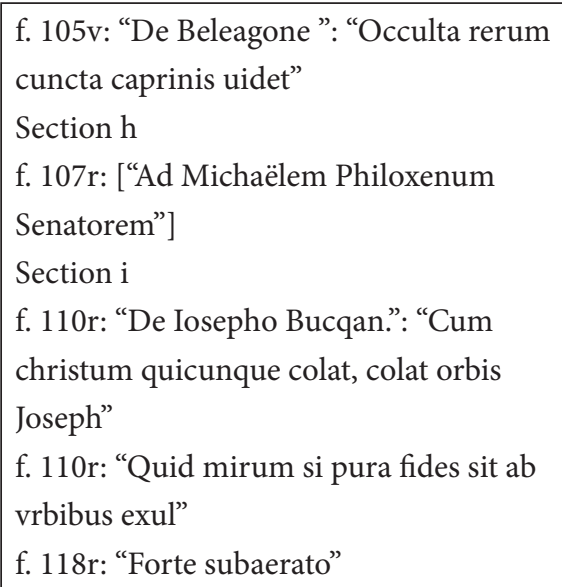

From this, it can be seen that a number of unpublished poems occur several times, while others appear only once. In the first category are to be found several of the satirical epigrams: "In monachum" (three times in 8140, once in 8141), "In Scaraboeum" (twice in 8140, once in 8141), the epigram on Leonora (twice in 8140), "De Iosepho" (three times in 8140, once in 8141). The Beleago poem, "Occulta rerum cuncta caprinis uidet," occurs only once, in 8140 , and there are a couple of other short anti-monastic poems accompanying one of the occurrences of "De Iosepho." Of the non-satirical poems, the one entitled "Omnia vincit amor" occurs in both manuscripts, while a long, unfinished poem with Old Testament themes occurs once only, in ms lat. 8141. There are also single instances of epigrams addressed to two different sets of brothers, the Montaigne brothers in ms lat. 8141, and the Hatté brothers in ms lat. 8140.

The reasons that these and other poems never found their way into print are probably quite varied. I have already referred to the fact that, despite his reputation as a highly accomplished poet, Buchanan was genuinely uninterested in seeing his secular poems appear in print. When attempts were made to publish them, it is with some reluctance that he agreed, and during his lifetime only the Fratres fraterrimi and the Franciscanus, ${ }^{3}$ followed by the Elegies, Silvae, and Hendecasyllables, ${ }^{4}$ appeared in print. In a letter to his friend Peter Daniel, dated 22 July 1566 and relating to the 1567 edition, he wrote: 
As far as I am concerned, I did not put much effort into saving them from destruction: for their subjects are almost all lightweight, and I do not know whether they are more a cause of displeasure or of shame for this age of ours. But since friends, whom I neither should nor can refuse anything, were so keen on them, amongst them Pierre de Montdoré in particular, I have collected some of them in my spare time, and arranged them under headings. There is a book of Elegies, a book of Silvae, and a book of Hendecasyllables, which I am now sending you. ${ }^{5}$

In 1568 , these two collections were brought together in a single volume published by Thomas Guarinus in Geneva. ${ }^{6}$ The Elegies, Silvae, and Hendecasyllables were again published together in 1579 in Paris, by Mamert Patisson, in a volume that also contains the Baptistes, and in some issues the ode "De Caleto recepta" (Miscellaneorum liber 1). The Iambi and the three books of Epigrams were first published posthumously, in 1584, along with part of the De sphaera ${ }^{7}$; the complete Miscellaneorum liber dates from $1615,{ }^{8}$ though poems that found their way into that collection were printed in 1590 by Israel Taurinus, and some had been printed separately as plaquettes around the time of composition. ${ }^{9}$ In contrast, the Psalm paraphrases did appear in full in 1565-66, with a further twenty editions or re-issues appearing during Buchanan's lifetime, ${ }^{10}$ while his plays were printed in 1544 (Medea), 1554 (Iephthes), 1556 (Alcestis), and 1577 (Baptistes). ${ }^{11}$ Buchanan seems to have been fully engaged not only in the publication but also in the revision of the Psalm paraphrases, as Roger Green demonstrates, which inevitably leads to the conclusion that he cared considerably more for the fate of these poems than for the secular poems. It was, of course, in the first complete edition of the Psalm paraphrases that Buchanan was dubbed "poetarum nostri saeculi facile princeps."

One reason for this difference in attitude towards the two collections undoubtedly concerns Buchanan's role as a senior statesman in the Reformed Church. On his return to Scotland some time in 1560 or 1561, Buchanan declared himself a Calvinist, and soon became an influential member of the Church of Scotland, being a member of its General Assembly from 1563 onwards and being elected Moderator on 25 June $1567 .{ }^{12}$ He would later become James VI's tutor in 1570 and Guardian of the Privy Seal in the same year. His reputation as one of the leading Protestants in Europe was secure, and he may well have wished to manage his public image with respect to his printed works. 
His friend Théodore de Bèze had in later life been severely criticized by Catholic polemicists for his youthful indiscretions in the Iuvenilia (as we have noted) and Buchanan may well have wished to avoid this problem. The poems that did appear in his lifetime are all relatively safe, either because they represent Protestant points of view, in the case of the Franciscanus and the Fratres fraterrimi, or because they are quite decorous, in the case of the Elegies and the Silvae. This is far from being the case with some of the unpublished poems, of which the hendecasyllabic poem "In Scaraboeum" is one of the most prominent. The Fratres fraterrimi, which certainly do not pull their punches, already had an epigram addressed to this figure (23), ${ }^{13}$ but the unpublished poem is one of Buchanan's most obscene:

Quod instar tibi mentulae caninae

Exerta est Scaraboee semper illa

Captatrix manus osculationum

Tractratrix puerilis illa culi

Merdis illa peruncta pridianis

Comem te et facilem putas videri.

Scis quam falsus opinione vana es :

istam qui sine nausea osculatur,

Et culum sine nausea osculetur,

Et nares vetulae febriculosae

Exugat sine nausea, et recenti

Cunni a fornice putre virus vdi

Cruda et toxica menstrui fluoris,

Et spurcas gravidae suis secundas,

Et canis vomitus et ova ranae

Et albam sanie vlceris lacunam,

Et aestu e cruribus luem liquatam,

Et quicquid sine nausea videri

Non potest, sine nausea osculetur. (BnF ms lat. 8140, f. $\left.9^{\text {r }}\right)^{14}$

Obviously, this is quite a virtuoso piece of vituperation in the Catullan style, which borrows to some extent from Catullan vocabulary (mentula, osculatio, febriculosus $)^{15}$ as well as from certain Catullan themes. The poem's success is reliant on the crescendo of foul, largely sexually-related, objects of disgust that 
the poet piles up, along with the repetition of "sine nausea." Despite the relative degree of permissiveness accorded to neo-Latin poets in the area of obscenity, it is understandable that a leading member of the Reformed Church of Scotland might not wish this poem to appear in his Opera omnia or that his friends might wish to exclude it for the same reasons. This may also explain why Buchanan's version of a French epigram concerning a monk having sex with a nun (though certainly fitting in with Protestant anti-monasticism) also failed to make it into the Fratres fraterrimi. The nun fears that she will lose her soul by her actions, but the "pius antistes" advises her that he will stop it escaping from the front, if she just makes sure that it does not get out through the "back door" (posteriore porta). ${ }^{16}$

"Omnia vincit amor" (52 lines in length) contains no obscenity, though it is perhaps its ending, with its sense of helplessness in the face of love, that determines its exclusion from print. The bulk of the poem is dedicated to the idea that the poet is seeking relief from the tyranny of love by devoting himself to hunting: "So, farewell, Cupid; I am seeking the chaste haunts of Diana, if only I can be freed at last from this love". Much of the poem is devoted to a description of the hunting activities that will replace his previous amorous ones, but the poem concludes:
Although I wished with these words to avoid the flames of Cupid, I felt I had become more aflame at last. Alas, savage Cupid controls my heart which he possesses, and cruel love reigns within my breast, and sleep does not allow me to be embraced deep in his bosom. Burning torches seer my breast. Alas, Cupid now has taken up the weapons which had fallen. Cupid, everything gives way to your commands. ${ }^{17}$

This expression of the power of love is unusual in Buchanan's poetry. Although the Neaera poems do appropriate Petrarchan and neo-Catullan themes, they tend to be less personal, while the Leonora cycle contains strong misogynistic elements. Once again, this poem may have been felt to be inappropriate for inclusion among the Elegies, where it would have most easily featured, because of its more serious tone in comparison to the Neaera poems there.

Another poem which is popular in the manuscripts but omitted from print is "De Iosepho," entitled more fully in one place "G. Buchanani de Sanctaemiliana schola in qua S. Josephi die pueri non feriabantur" (George 
Buchanan's poem on the school in Saint-Emilion in which the boys enjoyed no holiday on the feast of St Joseph, BnF ms lat. 8140, f. $102^{\mathrm{r}}$ ). It reads as follows: ${ }^{18}$

\begin{abstract}
Although whichever part of the world honours Christ also honours Joseph, why is it that this house does not honour him along with all the others? Perhaps because it is not religious? None is less impious. Perhaps they don't think he is a saint? Yes, they do. But he was always accompanied by a lazy ass; this house is not open to lazy asses. ${ }^{19}$
\end{abstract}

It is hard to see why this relatively innocuous poem did not make it into the published works, unless perhaps it was considered too parochial to be of international interest.

However the long poem addressed to Michel de L'Hospital ("Ad Michaelem Philoxenum Senatorem," ms lat. 8140, ff. $107^{\mathrm{r}-\mathrm{v}}$ ), which appears only once among Buchanan's unpublished works, is unlikely to have been penned by him, as McFarlane suspected. ${ }^{20}$ Its opening refers to the author's having given up writing poetry in French, and there is no evidence that Buchanan ever did this: "Scribere me insuetos forsan mirabere versus / Docte Philoxene, Musas \& tractare Latinas, / Posthabitis Gallis, nobis quae aliquando fauebant." (You will no doubt be surprised, learned L'Hospital, that I am writing unwonted poetry, following the Latin Muses and abandoning the French ones, who once favoured me.) One wonders, given the close association between Michel de L'Hospital and the circle of Jean de Morel in Paris, whether the author of this piece may be Joachim Du Bellay, probably the best known member of that circle to move from writing in French to composing in Latin during his period in Rome.

However, one other long composition, which makes a single appearance, and which is unmistakably by Buchanan, is the iambic poem directed against Beleago, clearly fitting into the series of poems that Buchanan wrote in Portugal against this man. It follows on from a manuscript version of Iambi 9, also addressed to Beleago, but in which the first twelve lines of the text of the published version of the poem are omitted. The unpublished poem is relatively long (37 lines), and plays on the reputation that the Portuguese teacher Belchior Beliagoa had gained for profiteering from his butcher's business as well as from teaching scholastic philosophy. ${ }^{21}$ Although, unlike other unfinished poems in this manuscript, there is no indication that this piece was not complete, this would in fact seem to be the case judging by the inconclusive ending: 
Occulta rerum cuncta caprinis videt

Beleago in extis temporis nostri Tages.

Et e macello philosophus prodit novus,

Zenonis acsi prodeat de porticu.

Non ille libros, et veternoso situ

Voluit sophorum scripta veterum squalida

Vt colligatur capra, ita adversarium

Inquit ligabis syllogismi vinculis.

Iugulo cruoris unda cum refunditur

Hic est elenchus verus. At quoties loco

Veruecis hircum ponit, est sophisticus.

Dum conqueruntur id sodales, ilico

Ultro, citroque per categorias genus,

Speciesque carnis, atque differentiae

Diiudicantur, pulmo, cor, iecur, ilia,

Caput, pedesque cum vorat dialectices

Elementa prima nomina, \& verba haec vocat,

Tibicinesque syllogismi, et sublicas.

Caro in minutas offulas cum caeditur

Analysis haec est, pingue si fecit suum

Ius publicanos iure fraudando suo

Inventioni quaestuosam comparat

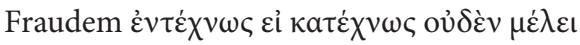

Sensim per istos erigens sese gradus

Secreta sophiæ in penetralia pervenit.

Materia prima est capra. Sed quoties ovis

Conditur instar, accipit formam novam.

Si forte fugit hircus, aut casu periit,

Tum motus extra surgit, ac vacuum domi.

Ieiuniumque indicitur causarium.

Et mille causæ suppetunt, non quattuor.

Si sicca pallet macilentia caro,

Causatur astra, aut sæua cancri brachia

Incendit æstus, aut leone torrido

Siticulosis aret herba pascuis, 
Aut frigus urit arua, uel sub sidere

Pluuiae capellæ campi inundant imbribus. (BnF ms lat. f. $\left.105^{v}\right)^{22}$

The humour of this poem relies on deliberately confusing the activities of butchery and philosophy, in part through the use of puns as in lines 20-21, where ius refers to both the stock or broth made by cooks and the notion of right: suo iure can either mean cooked "in its own stock" or "in his own right." Beleago's deceitfulness is also referred to, passing off goat for lamb (1l. 26-27) with an analogy to prime matter being converted into other forms, or offering excuses at the end for why his meat is poor quality. The poet unfortunately appears not to have managed to find a suitable pointe with which to conclude this witty piece of writing.

This state of incompletion is explicitly the case with a hexameter poem that occurs once only in ms lat. 8141 , ff. $28^{\mathrm{v}}-29^{\mathrm{r}}$, and whose opening line is, unfortunately, partly obscured by a large ink blot. The last line is followed by "Reliqua desunt." The themes of the poem are taken from the Old Testament, and may date from Buchanan's interest in the Psalms. McFarlane refers to it as a "versified narrative concerning some of the more depressing events of the Old Testament." ${ }^{23}$ They include Eve's temptation of Adam ("Et lætos sine fine dies, nisi prodita fraude / Fœmina coluisset vetito ieiuna pomo," 11. 4-5); the murder of Abel by Cain ("Caynus / Polluit innocuam fraterno sanguine terram," 11. 7-8); Noah's ark and the flood ("aquis meritum stagnantibus orbem / Vix foret una domus qua clausa superstite cymba / Se viua servaret mundi rediuiua futuri," 11. 13-15); Sodom and Gomorrha ("si dira Gomorrha / Obsidione premit moti penetralia Lothi," 11. 21-22); but also Moses and the exodus from Egypt (1l. 32-44). In some ways, this is reminiscent of certain psalms such as 78, which recall events from elsewhere in the Old Testament, weaving them together to suggest a moral lesson.

\section{Conclusions}

It seems to me that a number of conclusions can be drawn on the reasons for the omission from Buchanan's published œuvre of these and the other unpublished poems in the two manuscripts under consideration. In the case of the more frequently occurring poems, which were probably quite well known through a fairly well established manuscript diffusion, either the obscenity of 
the poems may have been considered too excessive for them to be included, or their very specific nature, referring to a particular time and place, may have been felt to make them unsuitable for international publication. In other cases, we have seen that the poems were unfinished, which would have presented aesthetic problems. It is one thing for editors to publish the long but unfinished didactic poem De sphaera, another to include incomplete short poems. In the case of the spurious poem to Michel de L'Hospital, the uncertain authorship must certainly have been a factor. Other short poems may have been felt to be too inconsequential to appear, such as the poems to the Hatté brothers or to the Montaigne brothers. ${ }^{24}$ Others may have simply been lost to the early editors of, for example, the Epigrams, where, in any case, considerations of balance in the overall dispositio of the three books may have been a factor. Nathalie Catellani-Dufrêne has referred to these collections as being "carefully crafted, and carefully assembled," with a "complex and original" archtecture. This extends, she points out, to the equilibrium of book 2 where 33 epigrams addressed to contemporaries (the Iusta) are balanced by 33 on ancient figures (the Icones). ${ }^{25}$ Some of the unpublished poems may simply not have fitted into such a carefully arranged structure.

Nevertheless, the unpublished poems in the two manuscripts we have considered today and in other manuscripts provide us with an interesting insight into the side of Buchanan that he and his editors may not always have wanted us to see, offering greater depth to the portrait we have of him. Hopefully, it will not be too long before they appear in the long-awaited edition of his poetic works, which has been inaugurated by Roger Green with the edition of the Psalm paraphrases, and to which authors of this volume hope to contribute soon.

\section{Notes}

1. Ian McFarlane, "George Buchanan's Latin Poems from Script to Print: A Preliminary Survey," The Library 24, no. 4 (1969), pp. 277-332. On the printed editions, see also John Durkan, Bibliography of George Buchanan (Glasgow: Glasgow University Library, 1994), pp. 158-79 for the "Profane Poems before 1615."

2. Bèze's Poemata first appeared in Paris 1548, printed by Conrad Bade and Robert Estienne, while Muret's Iuvenilia came out in Paris, 1552, printed by the widow of 
Maurice de La Porte. Both men were considerably younger than Buchanan, Bèze being born in 1519, and Muret in 1526. Despite the fact that his early poems were often raised as a point of criticism against Bèze, who converted to Calvinism and left for Geneva in October 1548, he continued to reedit them, albeit in revised form. See Kirk M. Summers, A View from the Palatine: The Iuvenilia of Théodore de Bèze, text, translation, and commentary (Tempe, AZ: Arizona Center for Medieval and Renaissance Studies, 2001), pp. 453-54 for editions of Bèze's poems, and Juvenilia, édition critique, traduction, annotation et commentaire par Virginie Leroux (Geneva: Droz, 2009), for Muret's poems (see pp. 494-95 for contemporary editions).

3. Georgii Buchanani Scoti, Franciscanus. Varia eiusdem authoris poemata ([Paris?]: [Henri Estienne?], 1566).

4 Georgii Buchanani Scoti, Poëtarum nostri sæeculi facile principis, Elegiarum liber I, Sylvarum liber I, Endecasllabon Lib. I (Paris: Robert Estienne, 1567).

5. George Buchanan, Opera omnia, 2 vols., ed. Peter Burman (Leiden: Langerak, 1725). "Quod ad me attinet, non magnopere laborabam uti ea ab interitu revocarem; argumenta enim fere levia sunt, \& quorum hanc ætatem nescio pigeat magis an pudeat. Sed quia tantopere amici, quibus nihil denegare vel debeo vel possum, ea expetebant, in quibus in primis est Petrus Montaureus. Quædam per otium recollegi, \& in capita conieci. Liber est Elegiarum unus, Silvarum unus, Hendecasyllabõn unus, quos ad te in præsentia mitto" (vol. 2, p. 724). All English translations are mine.

6. Georgii Buchanani Scoti Poetae eximii Franciscanus \& fratres, quibus accessere varia eiusdem \& aliorum Poëmata quorum \& titulos \& nomina XVI. Indicabit pagina. (Geneva: Thomas Guarinus, 1568). This volume includes the Elegiae, the Sylvae, and the Odarum vel hendecasyllaborum liber unus, as well as three of Buchanan's plays, Medea, Alcestis, and Iephthes.

7. Georgii Buchanani Scoti Franciscanus et fratres, Elegiarum liber I, Silvarum liber I, Hendecasllabwn Liber I, Epigrammatwn Libri III, De sphora fragmentum (s.l.: s.n, 1584). John Durkan writes: "Assumed to have been printed in Geneva by Petrus Sanctandreanus," p. 173.

8. Georgii Buchanani Scoti, Poemata... (Edinburgh: Andrew Hart, 1615).

9. The Taurinus edition was entitled Selectorum carminum ex doctiss. poetis collectorum... libri quatuor (s.l.: Israel Taurinus, 1590). The De Caleto nuper ab Henrico II. Francorum rege invictiss. recepta appeared in Paris, 1558, printed by Robert Estienne, and, with a variant title (De Caleto nuper ab Henrico II recepta carmen), 
by Charles Estienne in the same year. On Buchanan's politically engaged poetry of the the 1550s, see Philip Ford, "George Buchanan's Court Poetry and the Pléiade," French Studies 34 (1980), pp. 137-52, and David Hartley, "Les Poètes français de la prise de Calais (janvier 1558)," Bibliothèque d'Humanisme et Renaissance 56 (1994), pp. 719-29.

10. See Durkan, pp. 71-126 for editions of the Psalms; and Roger P. H. Green, Poetic Paraphrase of the Psalms of David (Geneva: Droz, 2011), pp. 26-33, on the printing history of the Psalms.

11. See Durkan, pp. 30-70, for editions of Buchanan's tragedies. Medea (Paris: Michel Vascosan, 1544) also appeared in 1576 (Strasbourg, Nicolaus Wyriot); Alcestis (Paris: Michel Vascosan, 1556) was reprinted the following year, and also printed in Wittenberg in 1581 (Matthaeus Welack); Iephthes (Paris: Guillaume Morel, 1554) also appeared in 1557 (Paris, Michel Vascosan), and Graz (Zacharias Bartsch, s.d.); Baptistes (London: Thomas Vautrollier, 1577 and 1578), also appeared in Edinburgh (Henry Charteris, 1578), London and Antwerp (Iacobus Henricius, 1578), Frankfurt (André Wechel, 1578 and 1579), and Strasbourg (Nicolaus Wyriot, 1579).

12. On Buchanan's involvement with the Kirk, see Ian McFarlane, Buchanan (London: Duckworth and Co, 1981) pp. 215-25.

13. This was only the case in the 1568 Bâle edition, which has a variant too in line 3 . In other editions, the epigram is addressed "In quendam Praesulem." The Bâle text reads: "Cum te Mula vehit nihilo te indoctior ipso, / Et nitet (ut par est) murice uterque pari. / Ni proceres, Scaraboee colant te, et vulgus adoret; / Presbyteris, clamas, nullus habetur honos. / Non tum cessat honos, praesul cum spernitur excors, / Sed cum regnat ővoc, tum male cessit honos" (ed. cit., p. 50: "When a mule that is no less learned than yourself bears you, and both of you shine, as is fair, with equal amounts of purple dye, unless the top men worship you, Scaraboeus, and the people adore you, you exclaim that no respect [honos] is reserved for priests. Respect isn't wanting when a senseless prelate is being scorned, but when an ass [onos] rules, respect comes to a bad end.")

14. Translation: "Scaraboeus, because your hand is always stuck out, like a dog's prick, that hand which is on the look-out for kisses, that hand that loves to fondle boys' bums, that hand which is smeared with yesterday's shit, you think you're so smooth and cool. But you've no idea how wrong you are: anyone kissing that hand without throwing up would kiss an arse without throwing up, and suck out the nostrils of a poxy old woman without throwing up, and the foul emissions of a 
wet cunt fresh from the brothel, and the bleeding poisons of menstrual fluid, and the filthy afterbirth of a pregnant sow, and a dog's vomit, and frog's spawn, and a gaping open wound white with pus, and lust-induced seminal fluid, and whatever cannot be seen without throwing up, he would kiss without throwing up."

15. Mentula appears nine times in Catullus, osculatio once (carmen 48), febriculosus once (carmen 6). Catullus 97 taken as a whole contains much of the shocking humour to be found in Buchanan's poem.

16. "Cum monachus monacham premeret, gemebunda mihi, inquit / Vae misera haec inter ludicra perdo animam. / Quam pius antistes verbis solatur amicis / Inguinaque inguinibus osculaque ore premens / Hos aditus ego praecludam, tu ne exeat inquit / Quicquam animae porta posteriore cave." (As a monk was lying on top of a nun, she groaned out: "Alas I'm losing my soul in this sporting!" The pious priest consoles her with loving words, covering her loins with his loins, her mouth with his lips. "I'll close off these exits," he said, "you make sure that no part of your soul gets out by the back door.") I published this epigram in George Buchanan, Prince of Poets (Aberdeen: Aberdeen University Press, 1982), p. 70.

17. His ego cum dictis vitare Cupidinis ignes

Optarem sensi plus caluisse demum.

Heu possessa ferus versat iam corda Cupido,

Inque meo saevus pectore regnat amor

$\mathrm{Nec}$ me concludi sinit alto pectore somnus.

Ardentes urunt pectora nostra faces.

Heu quae deciderant iam tela Cupido resumsit.

Cedunt imperiis cuncta Cupido tuis. (BnF ms lat. 8141, f. 28 )

18. This short epigram presents a number of variants. This version is to be found in BnF ms lat. 8140, f. $110^{\mathrm{r}}$. On the cult of Saint Joseph in the sixteenth century in France, see Gary Ferguson, "A Prototype of the Modern Man: Saint Joseph in France, c. 1400-1650," in Masculinities in Sixteenth-Century France: Proceedings of the Eighth Cambridge French Renaissance Colloquium, 5-7 July 2003, ed. Philip Ford and Paul White (Cambridge: Cambridge French Colloquia, 2006), pp. 1-21. Ferguson points out that the feast of Saint Joseph was a recent one, first introduced in Rome in 1479 (p. 1), and that the saint was, among other things, closely associated with education (pp. 14 and 18).

19. Cum Christum quicunque colit, colat orbis Ioseph

Cur hunc cum reliquis non colit ista domus?

Quod pia fortassis non est? minus impia nulla est. 
Forsitan hunc divum non putat? imo putat.

Sed fuit ignavo semper comitatus asello;

Ignavis asinis non patet ista domus.

20. McFarlane, “George Buchanan's Latin Poems," p. 299.

21. The first eight lines of this poem were published by Paul J. McGinnis and Arthur H. Williamson, eds., in George Buchanan: The Political Poetry (Edinburgh: Scottish History Society, 1995), pp. 54-55.

22. Translation: "Beleago, the Tages of our age, sees all the secrets of the world in goat entrails. And he goes forth from his shop as a reformed philosopher, as if going forth from Zeno's Stoa. He does not thumb through the books and writings of the ancient thinkers, dusty from ancient neglect. "Just as the goat is tied up, so you will tie up your enemy in the chains of a syllogism," he says. "When a stream of blood pours out from the throat, this is a real refutation." But whenever he puts a he-goat in place of a castrated one, he is being sophistical. When his colleagues complain of this, right on the spot, back and forth, genus, species, and differentiae of meat are distinguished into categories-lung, heart, liver, loin, head, trotters-and when he devours the first elements of dialectic, he calls them nouns and verbs, the props and supports of the syllogism. When meat is carved up into tiny morsels, this is his analysis; if he has made his stock rich, he compares the lucrative fraud to inventio, by defrauding the tax collectors in his own right, skilfully or unskilfully he doesn't care. Gradually raising himself up through these steps, he reaches the innermost secrets of wisdom. Prime matter is a she-goat. But whenever it is seasoned like lamb, it takes on a new form. If it chances that a he-goat escapes or accidentally dies, then movement arises, and there is a void at home and an unhealthy fast is imposed. And a thousand reasons support this, not just four. If the dry meat is pale from leanness, he blames the stars: either the cruel claws of Cancer the crab are intensifying a heatwave, or scorching Leo is drying out the grass in the droughtinfected pastures, or frost is blighting the fields, or beneath rainy Capricorn the fields are flooding with the rains."

23. McFarlane, "George Buchanan's Latin Poems," p. 300.

24. See Philip Ford, "George Buchanan et Montaigne," Montaigne Studies: An Interdisciplinary Forum 13, nos. 1-2 (2001), La familia de Montaigne, ed. John O'Brien and Philippe Desan, pp. 45-63, for the text of the epigram addressed to Montaigne and his two brothers. 
25. Nathalie Catellani-Dufrêne, "Memorialisation in George Buchanan's Iusta", in George Buchanan, Poet and Dramatist, ed. Philip Ford and Roger P. H. Green (Swansea: The Classical Press of Wales, 2009), pp. 59-71, p. 59. 